\title{
Paenibacillus larvae subespécie larvae em produtos da colméia produzidose importados pelo Brasil: métodos de análise, perfis de resistência, isolamento de bacteriófagos e sua identificação por microscopia eletrônica de transmissão*
}

\author{
DULCE MARIA TOCCHETTO SCHUCH
}

\author{
Vladimir Pinheiro do Nascimento (Orientador - UFRGS) \\ Robert Heaviside Madden (Co-Orientador-Queen's University of Belfast, Reino Unido)
}

Banca: Dejair Message (UFV), Marisa R. I. Cardoso (UFRGS), Edna Ferronato (MAPA)

A Cria Pútrida Americana, doença conhecida internacionalmente pela sigla AFB (American Foulbrood), é uma das mais devastadoras enfermidades que acomete o estagio larval das abelhas Apis mellifera, cujo agente etiológico é o microrganismo Paenibacillus larvae subsp. larvae. Apenas a forma esporulada do agente é infectante, sendo a forma vegetativa inócua, tanto para as crias como para as abelhas adultas. A doença é produzida pela ingestão de esporos do agente por larvas de menos de 3 dias de vida. A enfermidade se manifesta tanto em crias de operárias, como de machos e de rainhas. Até o momento, a Cria Pútrida Americana não foi diagnosticada no Brasil e ainda não havia sido registrado o isolamento do agente etiológico da enfermidade em produtos e/ou materiais apícolas produzidos no país. Esta tese está constituída dos resultados de sete experimentos relacionados com o tema. O primeiro foi o estudo de método analítico para a deteç̧ão de esporos do agente que resultou na publicação denominada "An improved method for the detection and presumptive identification of Paenibacillus larvae subsp. larvae spores in honey”. Esta metodologia foi adotada como método oficial brasileiro, tendo sido publicada no Journal of Apicultural Research 40(2), pp.59-64, 2001. Com este método foi estudada uma região suspeita da ocorrência de Cria Pútrida Americana no Sul do Brasil que resultou no primeiro isolamento de esporos de Paenibacillus larvae subsp. larvae em produto da colméia no Brasil. Aplicando o mesmo método foram estudados 1412 lotes de mel e pólen importados pelo Brasil no período de 1998 e 2001. Do total de lotes analisados, 347 $(24,6 \%)$ se apresentaram contaminados por esporos de Paenibacillus larvae subsp. larvae. Os perfís de resistência contra oxitetraciclina, sulfametazina e sulfatiazol demonstrados por 310 isolados de P.larvae subsp.larvae, selecionados de amostras de mel e pólen importados pelo Brasil de 5 diferentes países, foram avaliados. Somente 13 das 310 culturas estudadas (4,2\%) foram resistentes à oxitetraciclina, enquanto 227 (73,2\%) foram resistentes à sulfametazina, 198(63,8\%) foram resistentes ao sulfatiazol, e 187 (60,3\%) foram resistentes a ambas as sulfas. Apenas 3,5\% (11 culturas) foram resistentes a todos os antimicrobianos testados. Ao acaso, foram detectados 6 fagos temperados de culturas de P.larvae subsp. larvae durante os ensaios de sensibilidade aos antimicrobianos. Foi estudada a ocorrência de fagos líticos diretamente do mel e pólen, o que resultou no isolamento 9 bacteriófagos líticos. Dois lisados foram submetidos a microscopia eletrônica de transmissão em JEOL JEM 1200 - 120 Kv e resultou na observação de um fago cúbico e 3 fagos cúbicos.

Descritores: Paenibacillus larvae subsp. Larvae, mel, pólen, Brasil, bacteriófagos, antimicrobianos, microscopia eletrônica de transmissão.

\footnotetext{
* Tese de Doutorado n 18 (Especialidade: Bacteriologia). 137f. Programa de Pós-Graduação em Ciências Veterinárias da Faculdade de Veterinária - UFRGS, Porto Alegre/RS. CORRESPONDÊNCIA: D. M. T. Schuch [dmtschuch@via-rs.net]
} 


\title{
Paenibacillus larvae subsp. larvae in Brazilian beehive materials and in beehive products imported to Brazil: analytical methods, resistance profile, bacteriophages isolation and their identification by transmission electron microscopy**
}

\author{
DULCE MARIA TOCCHETTO SCHUCH
}

\author{
Vladimir Pinheiro do Nascimento (Adviser - UFRGS, Brazil) \\ Robert H. Madden (Co-adviser - Queen's University of Belfast, United Kingdom)
}

Committee: Dejair Message (UFV), Marisa R. I. Cardoso (UFRGS), Edna Ferronato (MAPA)

American Foulbrood (AFB) is one of the most devastating diseases of larval stage of Apis mellifera, which is produced by Paenibacillus larvae subsp. larvae. The vegetative form of this microorganism is not pathogenic to larvae neither to adult bees, only the spore being infective to the brood. The disease is produced by the ingestion of spores by larvae of less than 3 days old. Larvae of drones, queens and workers are all susceptible to the disease. Until this moment, AFB was not diagnosed in Brazil and the isolation of its causative agent in products and/or apicultural materials in the country have not yet been reported. This thesis is constituted by results of seven experiments related to the subject. The first one was a study of analytical method for detection of P.larvae subsp. larvae, which resulted in a publication in the Journal of Apicultural Research 40(2), pp. 59-64, 2001, called "An improved method for the detection and presumptive identification of Paenibacillus larvae subsp. larvae spores in honey", This methodology was adopted as Brazilian official method. Through this method, an AFB suspected region of South of Brazil was studied, which resulted in the first detection of P. larvae subsp. larvae spores in Brazilian hive products. Applying the same method, 1412 batches of beehive products imported by Brazil during 1998 to 2001 were studied. From the total analysed batches, $24.6 \%$ were positive for P.larvae spores. The resistance profile against oxytetracycline, sulfamethazine and sulfathiazole of 310 P. larvae subsp. larvae strains, selected from samples of honey and pollen imported to Brazil from five different countries were assessed. Just 13 of the 310 studied cultures (4.2\%) were resistant to oxytetracycline, while 227 (73.2\%) isolates were resistant to sulfamethazine, $198(63.8 \%)$ were resistant to sulfathiazole, and 187 (60.3\%) were resistant to both sulfas. Only $3.5 \%$ (11 cultures) were simultaneously resistant to all 3 antimicrobials tested. By chance, temperate phages from cultures of P.larvae subsp. larvae were detected during the antimicrobial susceptibility studies. The occurrence of lytic phages directly from the honey and pollen were studied, which resulted in the isolation of 15 P. larvae phages, from which 9 were lytic phages and 6 were temperate phages. Two lysate were submitted to electron microscopy in a JEOL JEM 1200 at $120 \mathrm{kV}$ and resulted in the observation of 1 filamentous phage and 3 cubic phages.

Key words: Paenibacillus larvae subsp. Larvae, honey, pollen, Brazil, international market, bacteriophage, antimicrobial resistance, transmission electron microscopy.

** Doctoral Dissertation no. 18 (Field: Bacteriology). 137p. Postgraduate Program in Veterinary Sciences, Faculdade de Veterinária, Universidade Federal do Rio Grande do Sul (UFRGS), Porto Alegre/Brazil. CORRESPONDENCE: D. M. T. Schuch [dmtschuch@ via-rs.net]. 